\title{
Sediment-Pore Water System Associated with Native Sulfur Formation at Jade Hydrothermal Field in Okinawa Trough
}

\author{
Yuka Yokoyama, Yoshio Takahashi, Youko Miyoshi, \\ Jun-ichiro Ishibashi, and Shinsuke Kawagucci
}

\begin{abstract}
The subsurface sediment-pore water system in the Jade hydrothermal field was investigated along with pore water chemistry and X-ray absorption fine structure analysis for sediment samples. Sediments were collected by coring near the TBS vent (Core 1186MBL) and from near the Biwako vent (Core 1188MB), which are active hydrothermal vents with high $\left(320^{\circ} \mathrm{C}\right)$ and low $\left(90^{\circ} \mathrm{C}\right)$ temperature fluids, respectively. Core $1186 \mathrm{MBL}$ is characterized by occurrences of chimney fragments in the shallow part (2-9 cmbsf) and native sulfur in the deep part (6-19 cmbsf). The results of chemical analyses of the pore water suggest a seawater recharge from the seafloor into Core 1186MBL. This hydraulic characteristic of the pore water, which is commonly observed near active submarine hydrothermal vents, leads to oxidation of sulfide minerals in chimney fragments in the shallow part by the oxic recharged seawater. The resulting acidic and suboxic pore water is transported downward, and can form native sulfur in the deeper part of Core 1186MBL. Core 1188MB shows a wide distribution of native sulfur, and its pore water chemistry indicates anaerobic oxidation of methane below $8 \mathrm{cmbsf}$ and a mixing of seawater and hydrothermal fluid below $10 \mathrm{cmbsf}$. The mixing of acidic and anoxic hydrothermal fluid and seawater allows the precipitation of native sulfur in Core $1188 \mathrm{MB}$, and the uniform circumneutral $\mathrm{pH}$ condition despite the input of acidic hydrothermal fluid. The native sulfur deposits in the arc-back-arc hydrothermal fields provide important geochemical information that is useful to understand the subsurface sediment-pore water system involving hydrothermal fluids
\end{abstract}

Keywords

Native sulfur $\bullet$ Pore water chemistry $\bullet$ Seafloor hydrothermal system $\bullet$ XAFS

Y. Yokoyama $(\bowtie)$

Department of Earth and Planetary Systems Science,

Graduate School of Science, Hiroshima University,

1-3-1 Kagamiyama, Higashi-Hiroshima, Hiroshima 739-8526, Japan

e-mail: yoshiyukasris@gmail.com

Y. Takahashi

Department of Earth and Planetary Systems Science, Graduate School of Science, Hiroshima University,

1-3-1 Kagamiyama, Higashi-Hiroshima, Hiroshima 739-8526, Japan

Department of Earth and Planetary Science,

Graduate School of Science, The University of Tokyo,

7-3-1 Hongo, Bunkyo-ku, Tokyo 113-0033, Japan

Y. Miyoshi • J.-i. Ishibashi

Department of Earth and Planetary Sciences,

Graduate School of Sciences, Kyushu University, 6-10-1 Hakozaki,

Higashi-ku, Fukuoka 812-8581, Japan

S. Kawagucci

Precambrian Ecosystem Laboratory (PEL), Japan Agency

for Marine-Earth Science and Technology (JAMSTEC),

2-15 Natsushima-cho, Yokosuka, Kanagawa 237-0061, Japan 


\subsection{Introduction}

The Jade hydrothermal field is located at the northeast of the Izena Hole in the mid-Okinawa Trough back-arc basin behind the Ryukyu arc-trench system. The site has been the subject of numerous studies (Halbach et al. 1989; Sakai et al. 1990a, b; Ishibashi et al. 1995; Kinoshita and Yamano 1997; Marumo and Hattori 1999). The strong enrichment of volatiles (e.g., $\mathrm{H}_{2} \mathrm{O}, \mathrm{CO}_{2}$, and $\mathrm{SO}_{2}$ ) in arc-back-arc magmas results in an input of these volatiles in the hydrothermal fluid of the arc-back-arc hydrothermal systems (Gamo et al. 2006). Considerable $\mathrm{SO}_{2}$ input into the hydrothermal fluid produces acidic fluid, often resulting in native sulfur deposits in arc-back-arc hydrothermal systems (Marumo and Hattori 1999; Nakagawa et al. 2006; Embley et al. 2007; de Ronde et al. 2011).

In seafloor hydrothermal system, a mixing of anoxic hydrothermal fluid with oxic seawater produces a significant gradient of environmental factors such as $\mathrm{pH}$ and redox conditions at and below seafloor. These environmental factors in sediment-pore water system are, therefore, helpful in understanding seafloor hydrothermal circulation. The specific $\mathrm{pH}$ and redox conditions associated with hydrothermal fluid is often recorded by mineral compositions in sediment. The Jade field is characterized by layered or massive native sulfur (sulfur crust) (Marumo and Hattori 1999; Ishibashi et al. 2014). Precipitation of native sulfur can occur under a limited Eh-pH condition, or under high acidity and suboxic conditions close to the sulfide-sulfate boundary with a sufficient concentration of sulfur (Brookins 1987). This suggests that the presence of native sulfur indicates the limited $\mathrm{pH}$ and redox conditions of the system. Chemical speciation of redoxsensitive elements such as sulfur is also a useful method for estimating the redox condition of the system that includes the elements. In the last two decades, X-ray Absorption Fine Structure (XAFS) spectroscopy has become a common speciation technique for various natural materials because of its high elemental selectivity without sample destruction (Tsuji et al. 2012). In this study, XAFS spectroscopy was applied for speciation of sulfur $(\mathrm{S})$, iron $(\mathrm{Fe})$, and selenium $(\mathrm{Se})$ in sediments to understand the subsurface redox system in the Jade hydrothermal field. In addition, by combining pore water chemistry with the speciation study, the sediment-pore water system involving hydrothermal fluids was investigated in relation to the native sulfur formation.

\subsection{Sampling and Analyses}

The research site, Jade field, is located along the northeastern slope of the Izena Hole at water depths of 1,300-1,550 m. The detailed geological settings of this area are summarized in Ishibashi et al. (Chap. 27). In the hole, one black smoker venting chimney was discovered with $\mathrm{Mg}^{2+}$-free fluids of $320{ }^{\circ} \mathrm{C}$ at $1,350 \mathrm{~m}$ depth (TBS vent) (Sakai et al. 1990a; Ishibashi et al. 2014). At the southwest distal part of the Jade field, the seafloor is covered with sulfur crust, and an active hydrothermal vent was found at a depth of 1,520 $\mathrm{m}$ (Biwako vent); the hydrothermal vent fluid is $90{ }^{\circ} \mathrm{C}$ and associated with emanation of liquid $\mathrm{CO}_{2}$ bubbles. Sediment samples were collected by short coring using the Remotely Operated Vehicle (ROV) Hyper Dolphin during the NT10-17 cruise of the $R / V$ Natsushima in September 2010. Sediment cores were collected at $50 \mathrm{~m}$ southwest of the TBS vent (1186MBL), and adjacent to the Biwako vent (1188MB) using an MBARI-type corer $30 \mathrm{~cm}$ in length with bottom seawater. The sampling locations of the two sediment cores are shown in Fig. 44.1 (Miyoshi et al., Chap. 44).

After the recovery of the ROV, the MBARI core samples were cut horizontally into 1 to several $\mathrm{cm}$ in length, and the outer rim of the core in each layer was removed to avoid possible contamination and artifacts. A sediment subsample of several $\mathrm{cm}^{3}$ in volume was taken from each cut sediment core section and pressed to drain the pore water using a disposal syringe with a $0.45 \mu \mathrm{m}$ pore-size filter. The remaining portion of each subsample was stored in an airtight polyethylene bag with $\mathrm{N}_{2}$ gas at $4{ }^{\circ} \mathrm{C}$ for onshore analyses. Aliquots of the filtered pore water and bottom seawater samples were acidified by $\mathrm{HNO}_{3}$ for onshore ICPAES analysis to prevent mineral precipitation and microbial activities, and stored in a refrigerator with the other unacidified aliquots for onshore analysis. The following parameters for the filtered pore water and bottom seawater were measured onboard: $\mathrm{pH}$ was determined using a $\mathrm{pH}$ meter (Horiba $\mathrm{pH}$ meter and glass electrode); alkalinity was measured by potentiometric titration with $0.1 \mathrm{M} \mathrm{HCl}$; ammonium ion $\left(\mathrm{NH}_{4}{ }^{+}\right)$concentration was determined using the indophenol blue colorimetric method (Solorzano 1969); and hydrogen sulfide $\left(\mathrm{H}_{2} \mathrm{~S}\right)$ concentration was determined by the methylene blue colorimetric method (Cline 1969). The analytical precisions were estimated to be within $0.5 \%$ for $\mathrm{pH}, 5 \%$ for alkalinity, $7 \%$ for $\mathrm{NH}_{4}{ }^{+}$, and $5 \%$ for $\mathrm{H}_{2} \mathrm{~S}$.

In the onshore laboratory, the collected sediment samples were treated in an anaerobic glove box (Coy Laboratory Products) purged with an atmosphere of $\mathrm{Ar} / \mathrm{H}_{2}$ (95:5) mixture, in which the oxygen content was monitored and kept below $0.01 \mathrm{mg} / \mathrm{L}$. The mineralogy of the sediment samples was analyzed using a powder X-ray diffracometer (XRD; MultiFlex, Rigaku Co.). To determine the bulk mineralogy, each sediment sample was ground and homogenized using agate mortar after drying in the glove box. The mineral phase identification was carried out by matching the XRD patterns to reference materials from the International Center for Diffraction Data (ICDD) database. 
For speciation analysis by XAFS, the sediment samples were re-packed into airtight polyethylene bags in the glove box without drying and stored at $4{ }^{\circ} \mathrm{C}$ until the XAFS measurements. The XAFS spectra were obtained at beamlines BL-9A and BL-12C at the KEK Photon Factory (Tsukuba, Japan). The measurements were carried out at room temperature under ambient conditions. Iron and Se K-edge XAFS spectra of the reference compounds were collected in transmission mode, whereas those of the sediment samples were obtained in fluorescence yield (FY) mode using a 19-element germanium semiconductor detector positioned at $90^{\circ}$ to the incident beam. In the fluorescence mode, the samples were positioned at $45^{\circ}$ with respect to the incident beam. Sulfur Kedge XAFS spectra were collected both by the fluorescence and conversion electron yield (CEY) modes in a chamber purged with helium to minimize the attenuation of incident X-rays by air. For the sulfur K-edge CEY-XAFS measurement, each sediment sample was directly attached to carbon double-faced tape on a sample holder and set in the chamber soon after taking it out of the polyethylene bag. The XAFS data were analyzed using the Athena program (Ravel and Newville 2005). XAFS consists of X-ray Absorption Near Edge Structure (XANES) and Extended X-ray Absorption Fine Structure (EXAFS). Analysis of XANES spectra based on least-square Linear Combination Fitting (LCF) provides information about the oxidation state and coordination chemistry of the absorbing atom. The quality of the LCF is given by the residual value $(R)$ defined by

$$
R(\%)=\frac{\sum\left\{I_{\mathrm{dat}}(E)-I_{\mathrm{cal}}(E)\right\}^{2}}{\sum\left\{I_{\mathrm{dat}}(E)\right\}^{2}} \times 100
$$

where $I_{\text {dat }}$ is the absorption of the experimental spectra and $I_{\text {cal }}$ is the absorption calculated from the reference spectra. By a similar LCF technique, EXAFS provides information on the structural environment of the absorbing atom and complements the XANES analysis. The LCF was performed on the $k^{3}$-weighted EXAFS data using reference spectra by minimizing the residual of the fit. The quality of the fitting is given by the goodness-of-fit parameter $R$, defined as

$$
R(\%)=\frac{\sum\left\{k^{3} \chi_{\text {dat }}(k)-k^{3} \chi_{\text {cal }}(k)\right\}^{2}}{\sum\left\{k^{3} \chi_{\text {dat }}(k)\right\}^{2}} \times 100
$$

where $\chi_{\text {dat }}(k)$ and $\chi_{\text {cal }}(k)$ are the experimental and calculated data points, respectively.

Chloride $\left(\mathrm{Cl}^{-}\right)$and sulfate $\left(\mathrm{SO}_{4}{ }^{2-}\right)$ concentrations in the unacidified pore water and bottom seawater were determined by ion chromatography with up to $5 \%$ errors. The concentration of magnesium $(\mathrm{Mg})$ in the acidified pore water and bottom seawater was measured by ICP-AES within $3 \%$ error.

\subsection{Results}

\subsubsection{Mineralogy in the Sediments}

Core $1186 \mathrm{MBL}$ (19 $\mathrm{cm}$ in length) collected near the TBS vent mainly consists of mud matrix and is black (Fig. 31.1a). This black sediment is characterized by the appearance of black lumps at $2-9 \mathrm{~cm}$ below the seafloor (cmbsf) and yellow lumps 17-19 cmbsf, which were identified as sulfide minerals (sphalerite and galena) and native sulfur, respectively, by XRD analysis (Table 31.1). The sulfide lumps found 2-9 cmbsf are considered to be chimney fragments from the many sulfide inactive chimneys around the TBS vent. The results of the bulk XRD analysis showed common occurrences of quartz throughout the entire core, while their concomitant minerals show a vertical compositional variation: barite at $0-4 \mathrm{cmbsf}$, sphalerite $(\mathrm{ZnS})$ and galena $(\mathrm{PbS})$ at 2-9 cmbsf, and native sulfur and pyrite $\left(\mathrm{FeS}_{2}\right)$ at 6-19 cmbsf (Table 31.1). Core 1188MB (23 cm in length) obtained adjacent to the Biwako vent can be visually divided into two units. The top layer (0-2 cmbsf)
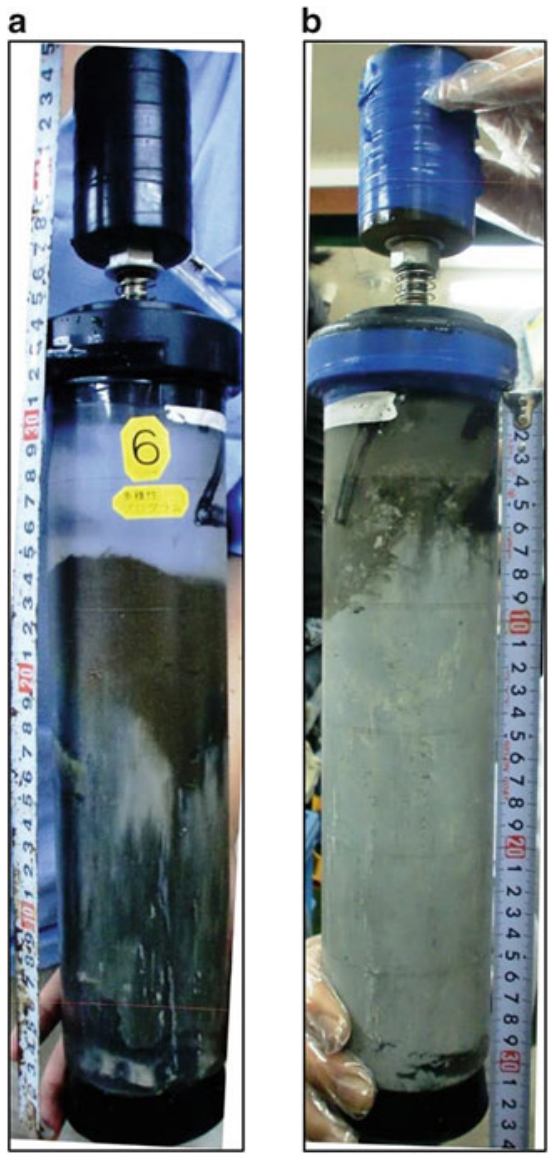

Fig. 31.1 Photograph of (a) Core 1186MBL collected near the TBS vent and (b) Core 1188MB obtained adjacent to the Biwako vent 
Table 31.1 Occurrences of minerals in the Core 1186MBL and Core 1188MB observed by bulk XRD analyses

\begin{tabular}{|c|c|c|c|c|c|c|c|c|c|c|}
\hline Depth (cmbsf) & Quartz & Native sulfur & Pyrite & Sphalerite & Galena & Barite & Illite & Smectite & Kaolinite & Chlorite \\
\hline \multicolumn{11}{|l|}{ Core $1186 M B L$} \\
\hline $0-2$ & $\mathrm{xxx}$ & & & $\mathrm{x}$ & $\mathrm{x}$ & $\mathrm{xx}$ & $\mathrm{x}$ & $\mathrm{xx}$ & $\mathrm{xx}$ & \\
\hline $2-4$ & $\mathrm{xx}$ & & & $\mathrm{xxx}$ & $\mathrm{x}$ & $\mathrm{xx}$ & $\mathrm{x}$ & $\mathrm{xx}$ & $\mathrm{xx}$ & \\
\hline $4-6$ & $\mathrm{x}$ & & & $\mathrm{xxx}$ & $\mathrm{xxx}$ & & $\mathrm{x}$ & $\mathrm{xx}$ & $\mathrm{xx}$ & \\
\hline $6-9$ & $\mathrm{xx}$ & $\mathrm{x}$ & $\mathrm{x}$ & $\mathrm{xxx}$ & $\mathrm{xx}$ & & $\mathrm{xx}$ & $\mathrm{xx}$ & $\mathrm{xx}$ & \\
\hline $9-11$ & $\mathrm{xxx}$ & $\mathrm{xxx}$ & $\mathrm{x}$ & & & & $\mathrm{xx}$ & $\mathrm{xx}$ & $\mathrm{xx}$ & \\
\hline $11-13$ & $\mathrm{xxx}$ & $\mathrm{xxx}$ & $\mathrm{x}$ & & & & $\mathrm{xx}$ & $\mathrm{xx}$ & $\mathrm{xx}$ & \\
\hline $13-15$ & $\mathrm{xxx}$ & $\mathrm{xxx}$ & $\mathrm{x}$ & & & & $\mathrm{xx}$ & $\mathrm{xx}$ & $\mathrm{xx}$ & \\
\hline $15-17$ & $\mathrm{xxx}$ & $\mathrm{xxx}$ & $\mathrm{x}$ & & & & $\mathrm{xx}$ & $\mathrm{xx}$ & $\mathrm{xx}$ & \\
\hline $17-19$ & $\mathrm{xxx}$ & $\mathrm{xxx}$ & $\mathrm{x}$ & & & & $\mathrm{xx}$ & $\mathrm{xx}$ & $\mathrm{xx}$ & \\
\hline \multicolumn{11}{|l|}{ Core $1188 M B$} \\
\hline $0-2$ & $\mathrm{xxx}$ & $\mathrm{x}$ & $\mathrm{x}$ & & & & $\mathrm{xx}$ & $\mathrm{xx}$ & & $\mathrm{xx}$ \\
\hline $2-4$ & $\mathrm{xxx}$ & $\mathrm{xx}$ & $\mathrm{x}$ & & & & $\mathrm{x}$ & $\mathrm{xx}$ & & $\mathrm{xx}$ \\
\hline $4-6$ & $\mathrm{xxx}$ & $\mathrm{xx}$ & $\mathrm{x}$ & & & & $\mathrm{x}$ & $\mathrm{xx}$ & & $\mathrm{xx}$ \\
\hline $6-8$ & $\mathrm{xxx}$ & $\mathrm{xxx}$ & $\mathrm{x}$ & & & & $\mathrm{x}$ & $\mathrm{xx}$ & & $\mathrm{xx}$ \\
\hline $8-10$ & $\mathrm{xxx}$ & $\mathrm{xxx}$ & $\mathrm{x}$ & & & & $\mathrm{x}$ & $\mathrm{xx}$ & & $\mathrm{xx}$ \\
\hline $10-11$ & $\mathrm{xxx}$ & $\mathrm{xxx}$ & $\mathrm{x}$ & & & & $\mathrm{x}$ & $\mathrm{xx}$ & & $\mathrm{xx}$ \\
\hline $11-14$ & $\mathrm{xxx}$ & $\mathrm{xxx}$ & $\mathrm{x}$ & & & & $\mathrm{x}$ & $\mathrm{xx}$ & & $\mathrm{xx}$ \\
\hline $14-17$ & $\mathrm{xxx}$ & $\mathrm{xxx}$ & $\mathrm{x}$ & & & & $\mathrm{x}$ & $\mathrm{xx}$ & & $\mathrm{xx}$ \\
\hline $17-20$ & $\mathrm{xxx}$ & $\mathrm{xxx}$ & $\mathrm{x}$ & & & & $\mathrm{x}$ & $\mathrm{xx}$ & & $\mathrm{xx}$ \\
\hline $20-23$ & $\mathrm{xxx}$ & $\mathrm{xxx}$ & $\mathrm{x}$ & & & & $\mathrm{x}$ & $\mathrm{xx}$ & & $\mathrm{xx}$ \\
\hline
\end{tabular}

Details of the clay mineralogy can be found in Miyoshi et al. (Chap. 44)

Mineral abundances determined by semi-quantitative XRD analysis: xxx, abundant ( $>25 \%)$; xx, common $(>10 \%)$; $x$, minor $(>3 \%)$.

appears grayish black, while the subsurface layer (2-23 cmbsf) was grayish white with a thin yellow layer (Fig. 31.1b). This grayish sediment is composed of quartz, native sulfur, and pyrite (Table 31.1 ). The native sulfur and pyrite are minor in the top layer compared with the subsurface layer. In addition to our bulk XRD analysis, Miyoshi et al. (Chap. 44) carefully identified the clay minerals for these two sediments. Their results showed that several clay minerals occur over the whole sediment sample (illite, smectite, and kaolinite in Core 1186MBL; illite, smectite, and chlorite in Core $1188 \mathrm{MB}$ ), which were produced by hydrothermal alteration (Miyoshi et al. Chap. 44).

\subsubsection{XAFS}

\subsubsection{Sulfur K-Edge XANES}

Sulfur K-edge XANES can distinguish the oxidation states of sulfur by peak-energy positions, as well as identify the species by the post-edge structure (Pingitore et al. 1995) (Fig. 31.2a). Since the total sulfur concentration in the sediment sample is high, the FY-XANES spectra for the sediment samples tended to be distorted because of the thickness effect or self-absorption effect (Schroeder 1996; Manceau et al. 2002). Therefore, the speciation of sulfur for the sediment samples was conducted based on the XANES spectra collected mainly by the CEY mode.
The results of the sulfur XANES analysis of Core $1186 \mathrm{MBL}$ indicated three types of XANES spectra along with sediment depth (Fig. 31.2b). The fractions of sulfur species for each spectrum are listed in Table 31.2. The XANES spectra for the upper-layer sediments $(0-4 \mathrm{cmbsf})$ show a prominent peak of sulfate species with post-edge structure of barite and with minor contribution of sphalerite. The abundances of barite and sphalerite are, however, almost equivalent because the peak intensity of barite is generally higher than that of sphalerite (Fig. 31.2a). In the intermediate layer sediments (4-9 cmbsf), sphalerite is the dominant sulfur species, but minor contributions of native sulfur and sulfate species were also found in the XANES spectra. Although identification of this sulfate species was difficult because of the absence of post-edge structure in the spectra, the spectrum of barite was used as a reference to determine the fraction of the sulfate species. Inconsistency between the observed and fitting curve around 2,470 eV for the 4-6 cmbsf sediment cannot be explained by the reference spectra of native sulfur and pyrite, and may have been caused by the thickness effect or self-absorption effect in the FY mode measurement. The sulfur species below 9 cmbsf were completely identified as native sulfur. The transition of the sulfur species with increasing depth is roughly consistent with the XRD data.

The sulfur XANES spectra for Core 1188MB show a peak originating from the native sulfur for all the depths studied here (Fig. 31.2c). Only the top layer of the sediment (0-2 cmbsf) contains a considerable amount of sulfate 

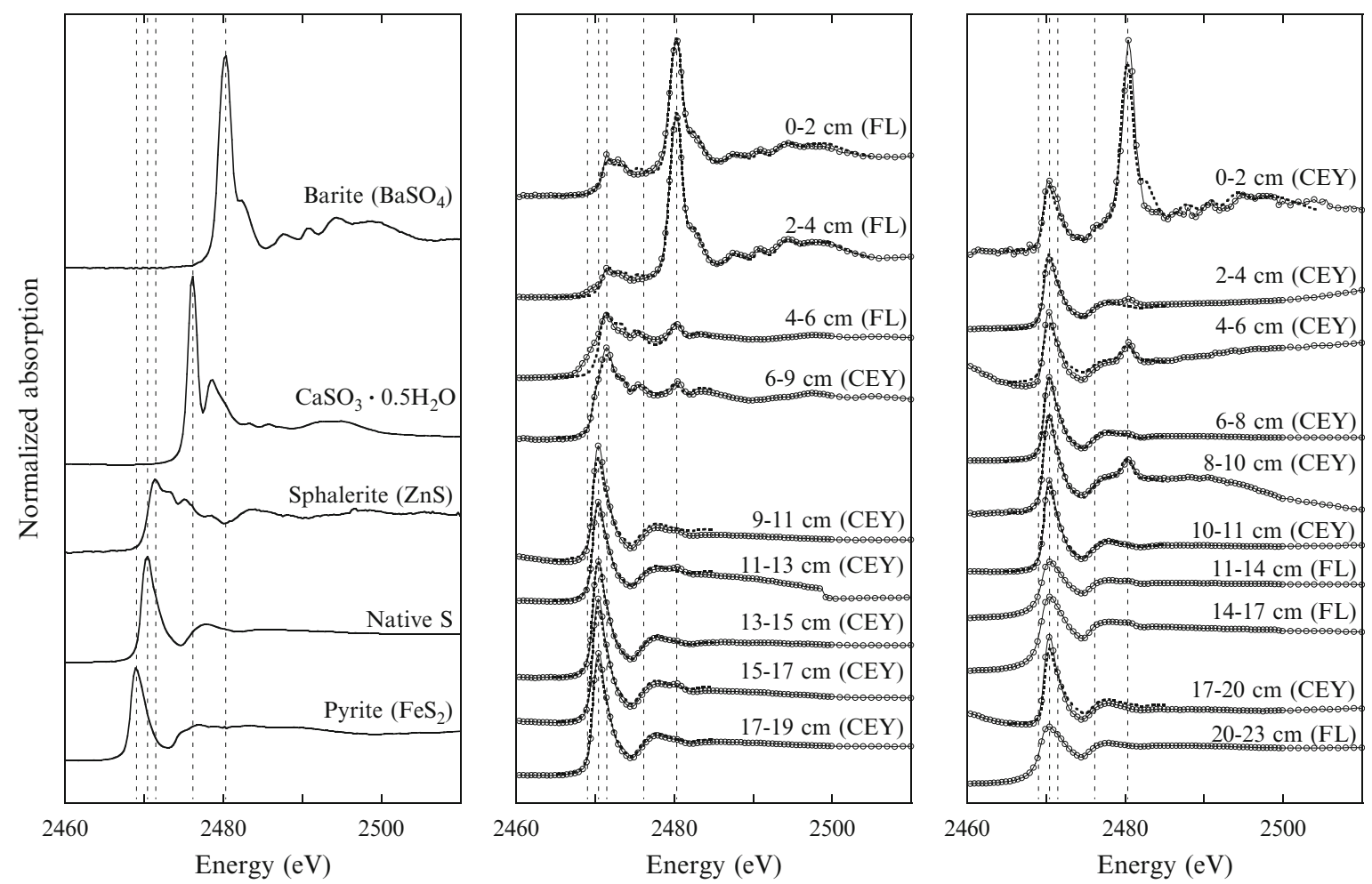

Fig. 31.2 Normalized sulfur K-edge XANES spectra for (a) sulfur reference materials, (b) Core 1186MBL, and (c) Core 1188MB. Dotted curves show the spectra simulated by the least-square fitting

Table 31.2 Linear combination fitting (LCF) results obtained by sulfur XANES for Core 1186MBL and Core 1188MB

\begin{tabular}{lllll}
\hline Depth (cmbsf) & Native sulfur & Spharelite & Barite & $\begin{array}{l}\text { Data collection } \\
\text { mode }\end{array}$ \\
\hline Core $1186 M B L$ & & & & \\
\hline $0-2$ & - & 50 & 50 & FY \\
\hline $2-4$ & - & 40 & 60 & FY \\
\hline $4-6$ & - & 90 & $10^{\text {a }}$ & FY \\
\hline $6-9$ & 25 & 70 & $5^{\text {a }}$ & CEY \\
\hline $9-11$ & 100 & - & - & CEY \\
\hline $11-13$ & 100 & - & - & CEY \\
\hline $13-15$ & 100 & - & - & CEY \\
\hline $15-17$ & 100 & - & - & CEY \\
\hline $17-19$ & 100 & - & - & CEY \\
\hline Core $1188 M B$ & & - & & \\
\hline $0-2$ & 44 & - & 56 & CEY \\
\hline $2-4$ & 100 & - & - & CEY \\
\hline $4-6$ & 87 & - & $13^{\text {a }}$ & CEY \\
\hline $6-8$ & 100 & - & - & CEY \\
\hline $8-10$ & 89 & - & $11^{\text {a }}$ & CEY \\
\hline $10-11$ & 100 & - & - & CEY \\
\hline $11-14$ & & & & FY \\
\hline $14-17$ & 100 & - & - & CEY \\
\hline $17-20$ & & & & FY \\
\hline $20-23$ & 100 & & & FY \\
\hline
\end{tabular}

${ }^{\mathrm{a}}$ Barite spectrum was used as a reference of sulfate species without postedge structure in XANES spectra species, which was identified as barite based on the postedge structure. The XANES spectra for the sediments from 11-14, 14-17, and 20-23 cmbsf could not be fitted with native sulfur or pyrite reference spectra. These spectra, which are distorted compared with other CEY-XANES spectra, are caused by the thickness or self-absorption effect in the FY mode. Judging from the peak energy of the spectra, native sulfur is likely to be dominant in these sediments.

\subsubsection{Iron K-Edge XAFS}

Iron K-edge XANES and EXAFS analyses are effective in iron speciation (O'Day et al. 2004). Three samples representing the top, intermediate, and bottom layers were selected from the sediment cores for the iron XANES and EXAFS measurement (Figs. 31.3 and 31.4). The fractions of each iron species obtained by LCF analysis by combinations of end-member spectra in the XANES and EXAFS analyses were similar (Table 31.3), suggesting that these fitting results are relatively reliable, since the XANES and EXAFS spectra have different physical-chemical origin and provide qualitatively different information. In Core $1186 \mathrm{MBL}$, about half of the iron was estimated to be in the clay minerals (illite and chlorite); the remaining fraction of the iron is ferrihydrite in the top layer $(0-2 \mathrm{cmbsf})$, and pyrite in the intermediate $(6-9 \mathrm{cmbsf})$ and bottom 
(17-19 cmbsf) layers. Since the XRD analysis did not confirm the presence of chlorite in Core 1186MBL, chlorite seems to be a minor component in the sediment. The chlorite identified by iron XAFS analysis is likely to correspond to Fe-Mg-chlorite of detrital origin (Marumo and Hattori 1999). Core $1188 \mathrm{MB}$ also contains ferrihydrite only in the top layer $(0-2 \mathrm{cmbsf})$. Pyrite and chlorite were found at all

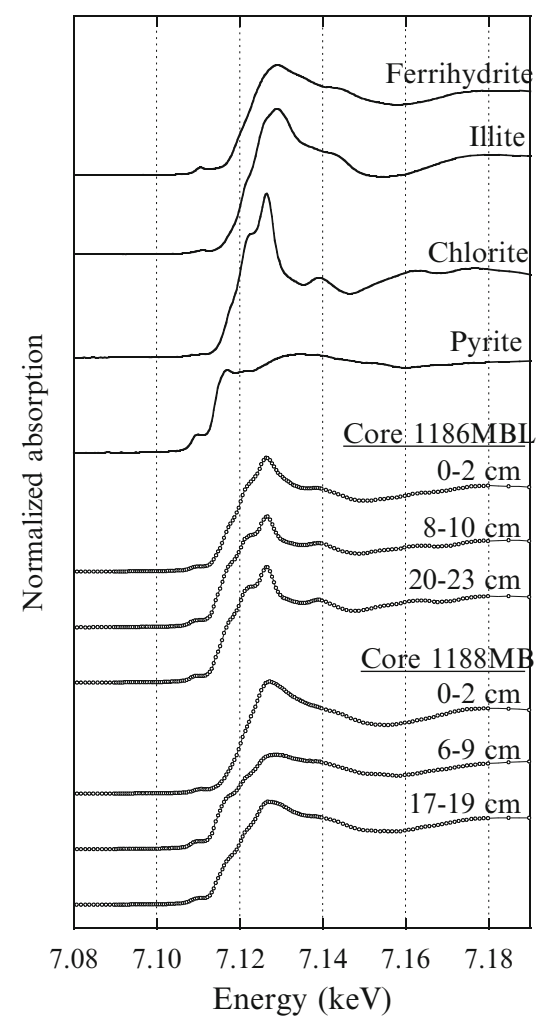

Fig. 31.3 Normalized iron K-edge XANES spectra for iron reference materials, Core $1186 \mathrm{MBL}$, and Core $1188 \mathrm{MB}$ the depths. The smaller fraction of pyrite in the top layer relative to the deeper layer agrees with the result from the XRD analysis. Considering the absence of pyrite in the sulfur XANES spectra, the amount of pyrite in the two sediments is significantly lower than that of the native sulfur at any depths studied here.

\subsubsection{Selenium K-Edge XANES}

Selenium XANES spectra were measured for sediment samples representing the top, intermediate, and bottom layers in the sediment cores. The selenium $\mathrm{K}$-edge position is generally sensitive to the valence of the selenium (e.g., Pickering et al. 1995); however, previous studies have indicated that

Table 31.3 Linear combination fitting results obtained by iron EXAFS for Core 1186MBL and Core 1188MB

\begin{tabular}{llllll}
\hline $\begin{array}{l}\text { Depth } \\
\text { (cmbsf) }\end{array}$ & Pyrite & Illite & Chlorite & Ferrihydrite & $\begin{array}{l}R \text { factor } \\
(\%)\end{array}$ \\
\hline Core $1186 M B L$ & & & & \\
\hline $0-2$ & - & 0.29 & 0.15 & $0.56(0.72)$ & 6.1 \\
& & $(0.10)$ & $(0.19)$ & & \\
\hline $6-9$ & 0.56 & 0.33 & 0.11 & - & 6.9 \\
& $(0.65)$ & $(0.24)$ & $(0.12)$ & & 5.5 \\
\hline $17-19$ & 0.40 & 0.46 & 0.14 & - & \\
& $(0.50)$ & $(0.34)$ & $(0.16)$ & & 7.2 \\
\hline Core $1188 M B$ & & & & 7.7 \\
\hline $0-2$ & 0.18 & - & 0.42 & $0.40(0.32)$ & \\
& $(0.29)$ & & $(0.39)$ & & 8.0 \\
\hline $8-10$ & 0.50 & - & 0.50 & - & \\
\hline $20-23$ & $(0.55)$ & & $(0.45)$ & & \\
& 0.44 & - & 0.56 & - & \\
\hline
\end{tabular}

Fraction of iron species determined by iron XANES analysis are shown in brackets. The $R$ values (the residual of the LCF in the iron XANES analysis) were $<1 \%$
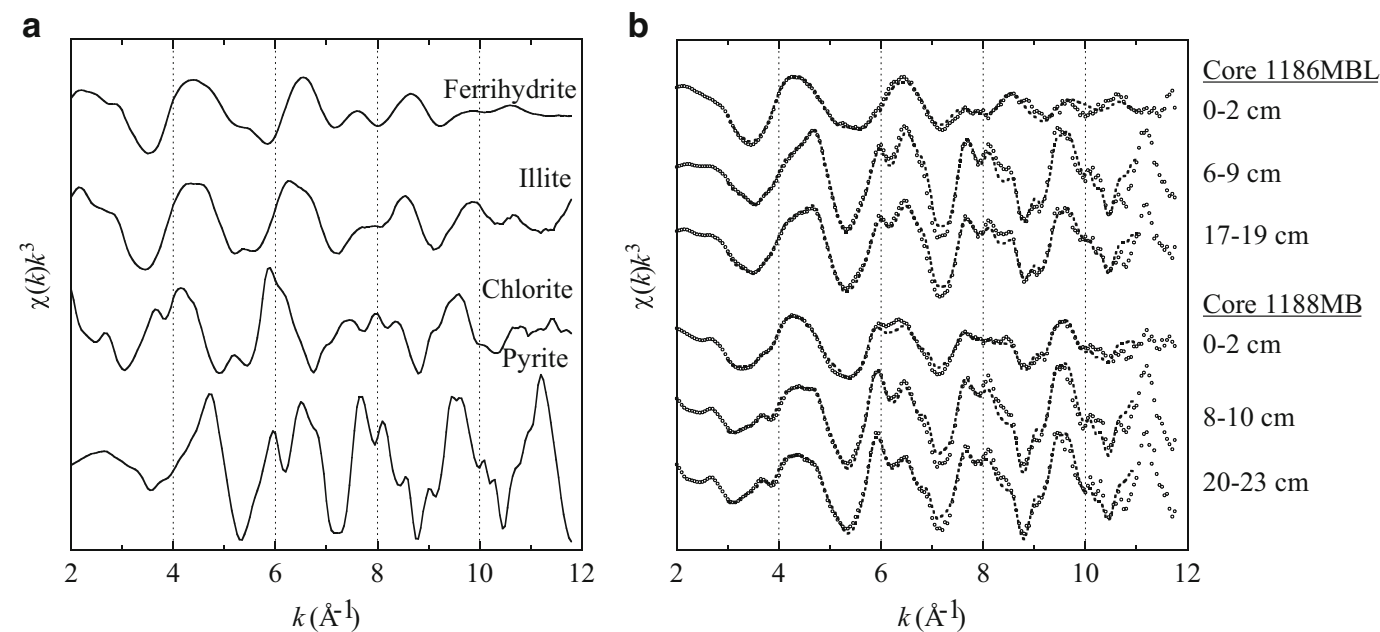

Fig. 31.4 Normalized $k^{3}$-weighted background-subtracted EXAFS data for (a) iron reference materials and (b) Core 1186MBL and Core $1188 \mathrm{MB}$. Dotted curves show the spectra simulated by the least-square fitting 


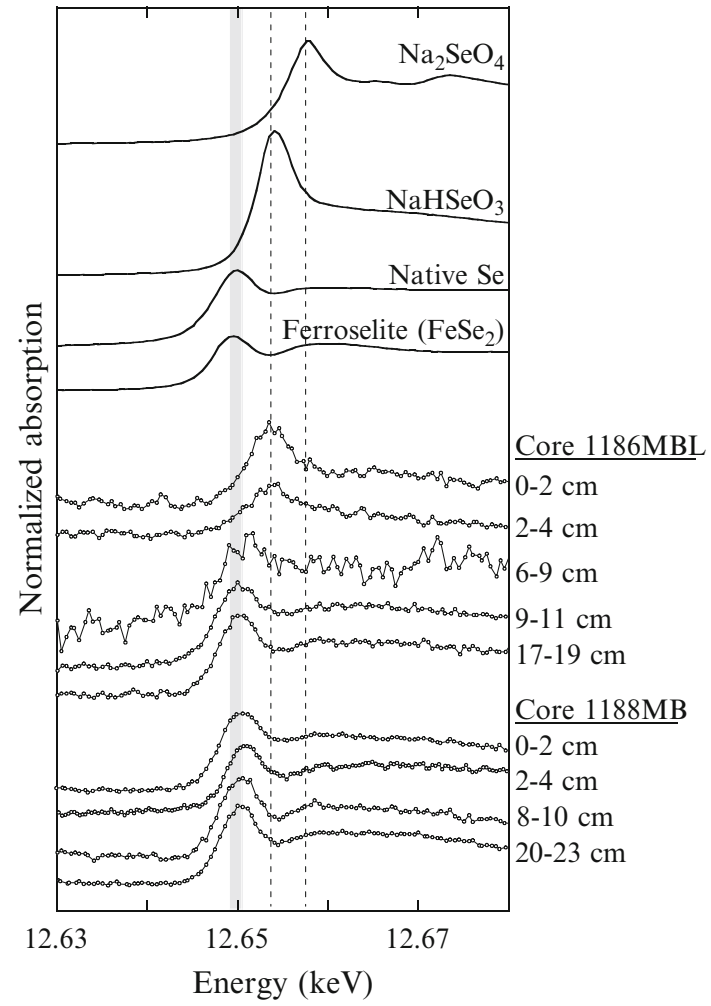

Fig. 31.5 Normalized selenium K-edge XANES spectra for selenium reference materials, Core 1186MBL, and Core 1188MB selenium K-edge XANES spectroscopy cannot easily distinguish between native selenium $\left(\mathrm{Se}^{0}\right)$ and selenide species $\left(\mathrm{Se}^{-\mathrm{I}}\right.$ and $\left.\mathrm{Se}^{-\mathrm{II}}\right)$ because of their close peak positions within $2 \mathrm{eV}$ (van Hullenbusch et al. 2007; Scheinost and Charlet 2008). In our analysis, the spectra of the native selenium and ferroselite $\left(\mathrm{FeSe}_{2}\right)$ also showed similar peak positions and structures (Fig. 31.5), indicating that native selenium and ferroselite cannot be distinguished clearly by selenium XANES spectra in this study. Most of the selenium XANES spectra of the sediment samples exhibited structures similar to those of native selenium and ferroselite (Fig. 31.5). The fact that the spectra showing native selenium and ferroselite were obtained for the samples below $6 \mathrm{cmbsf}$ in Core $1186 \mathrm{MBL}$ and for the samples in Core $1188 \mathrm{MB}$ is in good agreement with the distributions of native sulfur and pyrite determined by XRD, sulfur XANES, and iron XAFS analyses. Selenite $\left(\mathrm{Se}^{\mathrm{IV}}\right)$ was identified only in the upper layer (0-4 cmbsf) of Core 1186MBL.

\subsubsection{Pore Water Chemistry}

The results of pore water analyses for Core $1186 \mathrm{MBL}$ and Core $1188 \mathrm{MB}$ are summarized in Table 31.4 with the chemical composition of the Biwako hydrothermal fluid (Biwako fluid) reported by Ishibashi et al. (2014). The $\mathrm{H}_{2} \mathrm{~S}$ concentrations in most of the pore water samples were below the detection limit $(0.6 \mu \mathrm{mol} / \mathrm{L})$.

Table 31.4 Chemical composition in pore water for Core 1186MBL and Core 1188MB with that of Biwako hydrothermal fluid estimated by Ishibashi et al. (2014)

\begin{tabular}{|c|c|c|c|c|c|c|c|}
\hline Depth (cmbsf) & $\mathrm{pH}$ & $\mathrm{Mg}(\mathrm{mmol} / \mathrm{L})$ & $\mathrm{Cl}(\mathrm{mmol} / \mathrm{L})$ & $\mathrm{SO}_{4}{ }^{2-}(\mathrm{mmol} / \mathrm{L})$ & Alkalinity (mmol/L) & $\mathrm{NH}_{4}^{+}(\mathrm{mmol} / \mathrm{L})$ & $\mathrm{H}_{2} \mathrm{~S}(\mathrm{mmol} / \mathrm{L})$ \\
\hline \multicolumn{8}{|l|}{ Core 1186MBL } \\
\hline $0^{\mathrm{a}}$ & 7.6 & 53.8 & 569 & 29.9 & 2.42 & 0.007 & $<\mathrm{DL}$ \\
\hline $0-2$ & 7.6 & 56.0 & 567 & 27.3 & 2.63 & 0.031 & $<\mathrm{DL}$ \\
\hline $2-4$ & 7.6 & 59.8 & 588 & 30.5 & 2.21 & 0.027 & $<\mathrm{DL}$ \\
\hline $4-6$ & 7.2 & 58.3 & 578 & 29.6 & 0.84 & 0.039 & $<\mathrm{DL}$ \\
\hline $6-9$ & 5.1 & 57.8 & 569 & 28.5 & 0.07 & 0.034 & $<\mathrm{DL}$ \\
\hline $9-11$ & 4.4 & 56.2 & 567 & 28.6 & - & 0.028 & $<\mathrm{DL}$ \\
\hline $11-13$ & 4.3 & 54.2 & 575 & 28.7 & - & 0.040 & $<\mathrm{DL}$ \\
\hline $13-15$ & 4.3 & 55.6 & 731 & 36.1 & - & 0.035 & $<\mathrm{DL}$ \\
\hline $15-17$ & 4.8 & 55.7 & 613 & 29.1 & 0.06 & 0.036 & $<\mathrm{DL}$ \\
\hline $17-19$ & 4.4 & 64.8 & 572 & 28.8 & - & 0.025 & $<\mathrm{DL}$ \\
\hline \multicolumn{8}{|l|}{ Core 1188MB } \\
\hline $0^{\mathrm{a}}$ & 7.6 & 50.3 & 609 & 24.8 & 5.0 & 0.062 & 0.074 \\
\hline $0-2$ & 7.6 & 56.7 & 581 & 26.8 & 4.8 & - & $<\mathrm{DL}$ \\
\hline $2-4$ & 7.5 & 53.0 & 575 & 25.9 & 3.9 & 0.054 & $<\mathrm{DL}$ \\
\hline $4-6$ & 7.6 & 52.4 & 586 & 24.7 & 5.4 & - & $<\mathrm{DL}$ \\
\hline $6-8$ & 7.5 & 53.3 & 601 & 25.4 & 6.6 & - & $<\mathrm{DL}$ \\
\hline $8-10$ & 7.6 & 54.0 & 561 & 21.6 & 8.3 & - & $<\mathrm{DL}$ \\
\hline $10-17$ & 7.4 & 47.4 & 534 & 11.5 & 17.3 & 0.43 & $<\mathrm{DL}$ \\
\hline $17-23$ & 8.0 & 39.5 & 470 & 1.8 & 25.6 & - & $<\mathrm{DL}$ \\
\hline \multicolumn{8}{|c|}{ Biwako hydrothermal fluid } \\
\hline & 4.8 & 0 & 167 & 0 & - & 5 & 23 \\
\hline
\end{tabular}

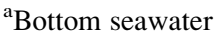


a
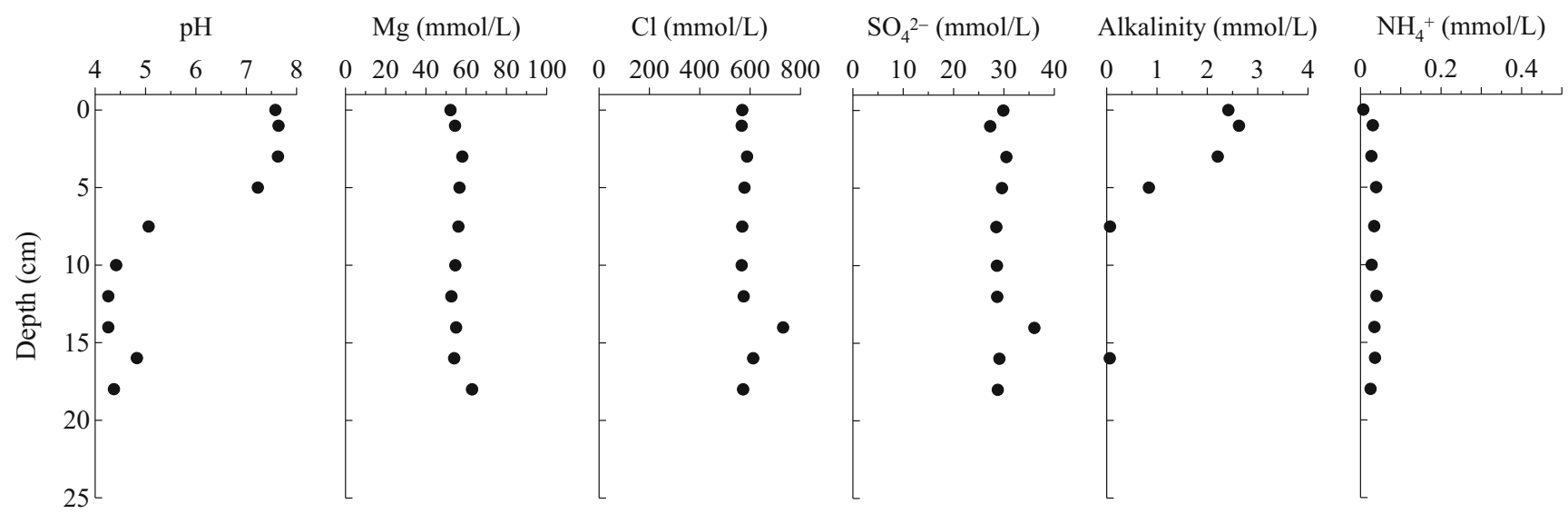

b
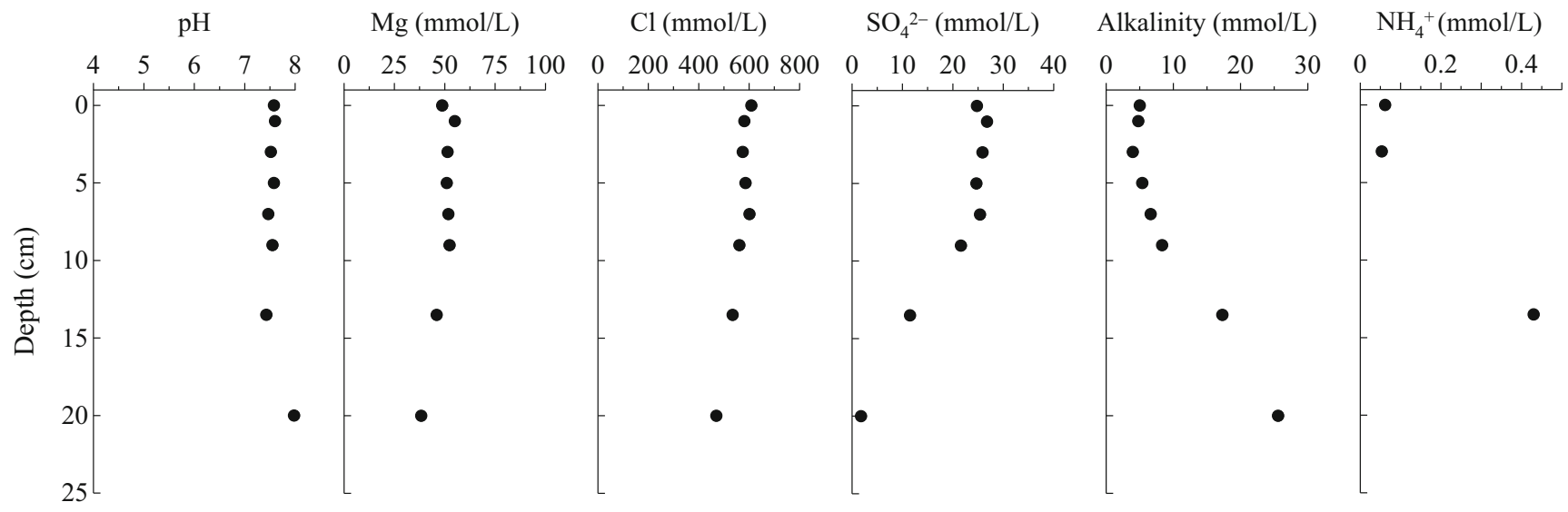

Fig. 31.6 Vertical profiles of $\mathrm{pH}$, alkalinity, and concentrations of $\mathrm{NH}_{4}{ }^{+}$, sulfate, chloride, and magnesium in the pore water for (a) Core $1186 \mathrm{MBL}$ and (b) Core $1188 \mathrm{MB}$

The pore water chemistry of Core $1186 \mathrm{MBL}$ is characterized by decreasing $\mathrm{pH}$ and alkalinity with increasing depth, and lower $\mathrm{pH}$ and alkalinity levels than those of the ambient seawater (pH 7.6 and $2.4 \mathrm{mmol} / \mathrm{L}$ of alkalinity) (Fig. 31.6a). The alkalinity could not be determined for pore water with a $\mathrm{pH}$ below 4.8. The $\mathrm{NH}_{4}{ }^{+}$concentration in the pore water did not rise above $50 \mu \mathrm{mol} / \mathrm{L}$ at any depth. Noteworthy, the pore water in the deeper layer (9-19 cmbsf) shows a $\mathrm{pH}$ of 4.2-4.9, suggesting that this unique pore water chemistry is unlikely to be explained only by a simple mixing between high-temperature hydrothermal fluid and ambient seawater, because the $\mathrm{pH}$ of the hightemperature hydrothermal fluid obtained from the TBS vent (Jade fluid) does not go below 4.7 (Sakai et al. 1990b; Ishibashi et al. 2014). The concentrations of sulfate, chloride, and magnesium in the deeper layer pore water are comparable to the ambient seawater levels, which also indicates a low contribution of hydrothermal fluid since depletions of sulfate and magnesium are common in the hydrothermal fluid (Ishibashi et al. 2014).
The pore water of Core $1188 \mathrm{MB}$ shows a profile characterized by significantly increased alkalinity and $\mathrm{NH}_{4}{ }^{+}$concentration and decreased sulfate, chloride, and magnesium concentrations with increasing depth (Fig. 31.6b). The alkalinity (up to $25.6 \mathrm{mmol} / \mathrm{L}$ ) is the highest among previously reported values for hydrothermal fluids and sediment pore water around vents in the Okinawa Trough hydrothermal systems (Gamo et al. 1991; Kawagucci et al. 2011). The $\mathrm{pH}$ values are maintained at the ambient seawater value throughout Core $1188 \mathrm{MB}$.

\subsection{Discussion}

\subsubsection{Core 1186MBL Collected Around the Black Smoker Vent}

Core 1186MBL contains abundant native sulfur below 6 cmbsf without any evidence of contribution of hydrothermal fluid in the pore water. The depth of the occurrence of 

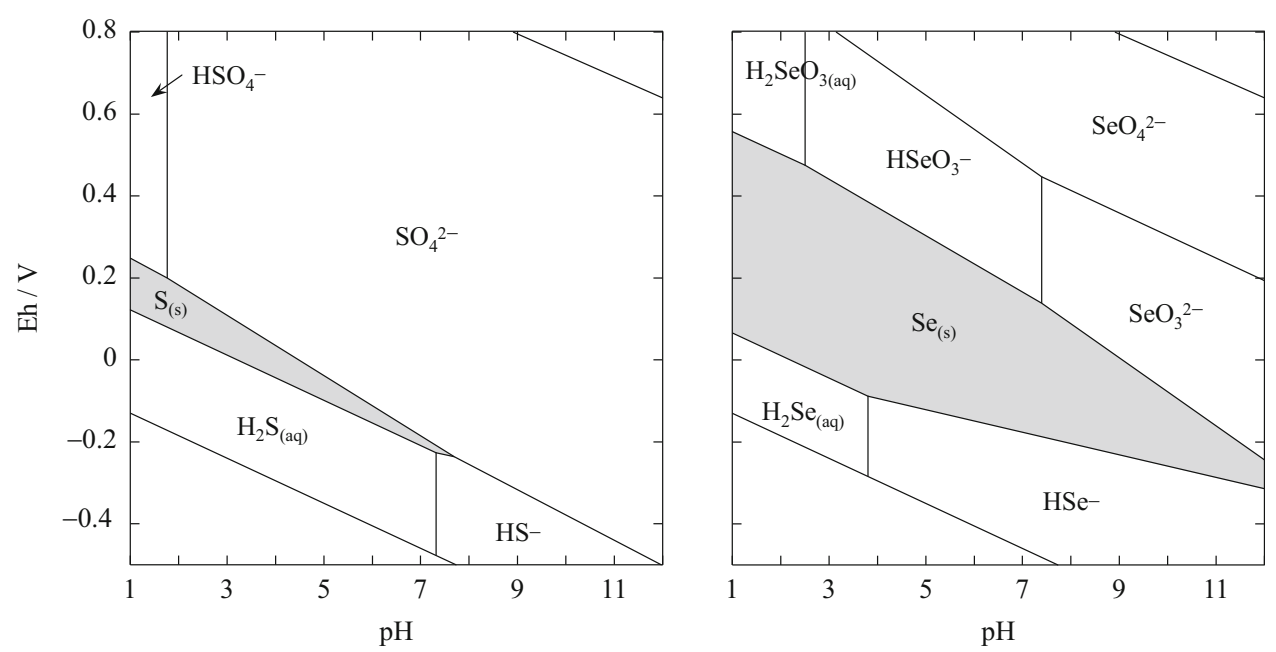

Fig. 31.7 Eh-pH diagrams for sulfur and selenium species at $5^{\circ} \mathrm{C}$ and $150 \mathrm{bar}$ total pressure. The $30 \mathrm{mmol} / \mathrm{L}$ of total sulfur and $1 \mathrm{nmol} / \mathrm{L}$ of total selenium concentrations correspond to seawater level and simulate the pore water condition in Core 1186MBL (i.e., recharging seawater). Diagrams were constructed by ACT2 module of the Geochemist's Workbench software with the "thermo.com.v8.r6+" database (Bethke 2011)

chlorite as shown by the iron XAFS analysis, suggesting that typical hydrothermal alteration at the Jade site is not widespread in Core 1186MBL.

Seawater level concentrations of sulfate, chlorite, and magnesium in the pore water in the deeper layer suggest the process of recharging of seawater into the subsurface sediments. Near active fluid venting site, such as TBS vent, pressure gradients associated with venting is known to induce the seawater recharge and to produce secondary fluid circulation cell below the seafloor (Stein and Fisher 2001). Incorporating oxic seawater into the subsurface sediments may retain a low concentration of $\mathrm{NH}_{4}{ }^{+}$, which is usually found under anoxic condition. The recharging seawater is acidified to $\mathrm{pH} 4.4$ within the intermediate layer (4-9 cmbsf). This acidifying layer corresponds to the occurrence of sulfide lumps. Acidification associated with sulfide oxidation is well known process in drainage from sulfidic mine (Nordstrom 1982; Moses et al. 1987). The oxic recharging seawater could lead to the oxidation of the sulfide lumps, such as sphalerite and galena:

$$
\begin{aligned}
& \mathrm{ZnS}+2 \mathrm{O}_{2} \rightarrow \mathrm{Zn}^{2+}+\mathrm{SO}_{4}^{2-} \\
& \mathrm{PbS}+2 \mathrm{O}_{2} \rightarrow \mathrm{Pb}^{2+}+\mathrm{SO}_{4}^{2-}
\end{aligned}
$$

However, oxidation of these minerals shows no contribution to the acidification. In sphalerite, iron can significantly substitute for zinc up to $15 \mathrm{~mol} \%$ (Baumgartner et al 2008). If iron substitutes for zinc, the sulfide oxidation occurs in a similar way as pyrrhotite $(\mathrm{FeS})$ :

$$
\mathrm{FeS}+2 \mathrm{O}_{2} \rightarrow \mathrm{Fe}^{2+}+\mathrm{SO}_{4}^{2-}
$$


In addition, oxidation of ferrous iron $\left(\mathrm{Fe}^{2+}\right)$ to ferric iron $\left(\mathrm{Fe}^{3+}\right)$ and precipitation of iron hydroxide under oxic condition acidify the pore water:

$$
\mathrm{Fe}^{2+}+\frac{1}{4} \mathrm{O}_{2}+\frac{5}{2} \mathrm{H}_{2} \mathrm{O} \rightarrow \mathrm{Fe}(\mathrm{OH})_{3(\mathrm{~s})}+2 \mathrm{H}^{+}
$$

Thus, sphalerite containing iron could be acid generator. Oxidation of pyrite is also known to be efficient acid producer by reaction in Eq. (31.9), followed by reaction in Eq. (31.8):

$$
\mathrm{FeS}_{2}+\frac{7}{2} \mathrm{O}_{2}+\mathrm{H}_{2} \mathrm{O} \rightarrow \mathrm{Fe}^{2+}+2 \mathrm{SO}_{4}^{2-}+2 \mathrm{H}^{+}
$$

Although the occurrence of pyrite is found only below $6 \mathrm{cmbsf}$, pyrite could contribute the acidification as one of sulfide minerals in the sulfide lumps. The absence of pyrite in the upper layer $(0-6 \mathrm{cmbsf})$ may suggest that most of pyrite in the chimney fragments is dissolved. The oxidations of sulfide minerals in the acidifying layer decrease the alkalinity of pore water from seawater level $(2.4 \mathrm{mmol} / \mathrm{L})$ to almost zero due to the productions of protons and sulfate ions.

The secondary fluid circulation transports the acidified pore water downward. Under acidic and suboxic conditions, stability of native sulfur increases because of its grater insolubility at low $\mathrm{pH}$ (Fig. 31.7). Thus, the native sulfur formation appearing below the acidifying layer is induced by the supply of acidic and suboxic pore water, and by simultaneous pyrite oxidation:

$$
\mathrm{FeS}_{2}+\frac{1}{2} \mathrm{O}_{2}+2 \mathrm{H}^{+} \rightarrow 2 \mathrm{~S}_{(\mathrm{s})}+\mathrm{Fe}^{2+}+\mathrm{H}_{2} \mathrm{O}
$$

Ferric iron is produced by oxidation of ferrous iron readily under acidic condition, and thus the ferric iron may become additional oxidant of pyrite, as follows:

$$
\begin{gathered}
\mathrm{Fe}^{2+}+\frac{1}{4} \mathrm{O}_{2}+\mathrm{H}^{+} \rightarrow \mathrm{Fe}^{3+}+\frac{1}{2} \mathrm{H}_{2} \mathrm{O} \\
\mathrm{FeS}_{2}+2 \mathrm{Fe}^{3+} \rightarrow 2 \mathrm{~S}_{(\mathrm{s})}+3 \mathrm{Fe}^{2+}
\end{gathered}
$$

Precipitation of native sulfur has the potential to form an inert layer on the pyrite surface, which inhibits the diffusion of oxidants to the surface and further dissolution of pyrite (Nordstrom 1982). The remaining pyrite in the native sulfur layer might be protect from acidic pore water by the native sulfur. The formation of native sulfur may extend below $19 \mathrm{cmbsf}$ as long as oxygen remains because of the downward flow of the acidic pore water. Hence, the native sulfur is considered to be formed by the supply of acidic and suboxic pore water, resulting from the oxidation of sulfide minerals by the recharging seawater, below 9 cmbsf in Core 1186MBL (native sulfur formation zone).

The redox transition from oxic to suboxic conditions also affects the chemical species of redox-sensitive elements in the sediment. The upper layer $(0-4 \mathrm{cmbsf})$ is characterized by the occurrences of iron oxyhydroxide (ferrihydrite), sulfate mineral (barite), and selenite, which are stable under the (relatively) oxic condition. These species are not found below $6 \mathrm{cmbsf}$ with the redox transition to suboxic condition. According to Eh-pH diagrams of sulfur and selenium, stable conditions of native sulfur fall within those of the native selenium under acidic condition (Fig. 31.7). The presence of native sulfur in the sediment supports that of native selenium, although distinguishing between native selenium and ferroselite was difficult by selenium K-edge XANES.

Kaolinite found in Core 1186MBL is generally formed under acidic condition. Marumo and Hattori (1999) indicated that the simple mixing of seawater and hydrothermal fluids in the Jade site is not sufficient to produce the acidic condition required for the formation of kaolinite. On the other hand, our analysis suggests that the sulfide oxidation process could produce pore water that is more acidic than the hydrothermal fluid, and thus may lead to the formation of kaolinite in Core 1186MBL.

\subsubsection{Core 1188MB Collected near the Biwako Vent}

The decreased magnesium, chloride, and sulfate concentrations with increasing depth imply a contribution of hydrothermal fluid below $10 \mathrm{cmbsf}$ (Fig. 31.6b). The decreasing chloride concentrations within the deeper layer (8-23 cmbsf) are correlated with the decrease in the magnesium concentration along the mixing line between the seawater (Mg: $55 \mathrm{mmol} / \mathrm{L} ; \mathrm{Cl}: 560 \mathrm{mmol} / \mathrm{L}$ ) and the Biwako fluid (Mg: $0 \mathrm{mmol} / \mathrm{L} ; \mathrm{Cl}: 167 \mathrm{mmol} / \mathrm{L}$ ) endmembers (Fig. 31.8a). It suggests input of Biwako fluid into the pore water below $10 \mathrm{cmbsf}$. The Biwako fluid originates mainly from the vapor phase produced by the phase separation of the original hydrothermal fluid (Jade fluid) (Ishibashi et al. 2014). Since Core $1188 \mathrm{MB}$ was located adjacent to the Biwako vent, it is reasonable to expect the input of Biwako fluid in the sample. Based on a decreasing rate of magnesium concentration between the seawater and the pore water at $10-17$ cmbsf $(47.4 / 55=0.86)$, the $\mathrm{NH}_{4}{ }^{+}$concentration in the pore water at $10-17 \mathrm{cmbsf}$ could be predicted as $0.75 \mathrm{mmol} / \mathrm{L}(=5 \times(1-0.86)+0.058)$, where the $\mathrm{NH}_{4}{ }^{+}$ concentration in the Biwako fluid is $5 \mathrm{mmol} / \mathrm{L}$ and the average $\mathrm{NH}_{4}{ }^{+}$concentration in the pore water above 10 cmbsf is $0.058 \mathrm{mmol} / \mathrm{L}$ (Table 31.4 ). This predicted value 
a $\mathrm{Mg}$ vs. $\mathrm{Cl}$

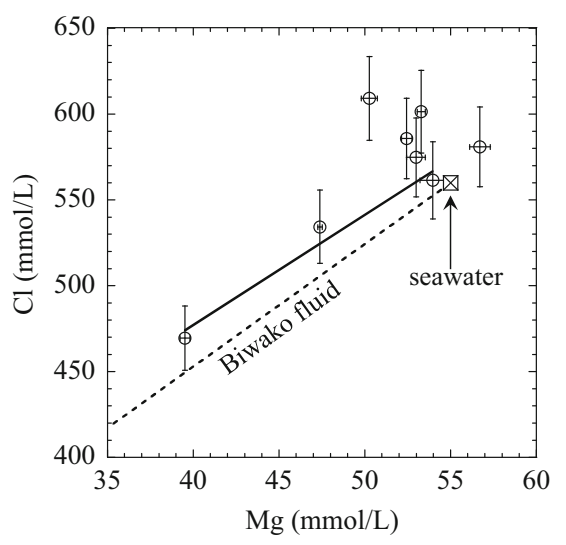

b $\mathrm{Mg}$ vs. $\mathrm{SO}_{4}{ }^{2-}$

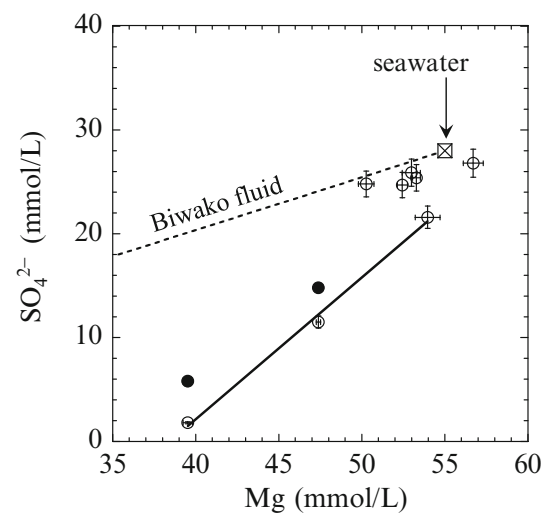

C $\mathrm{SO}_{4}{ }^{2-}$ vs. alkalinity

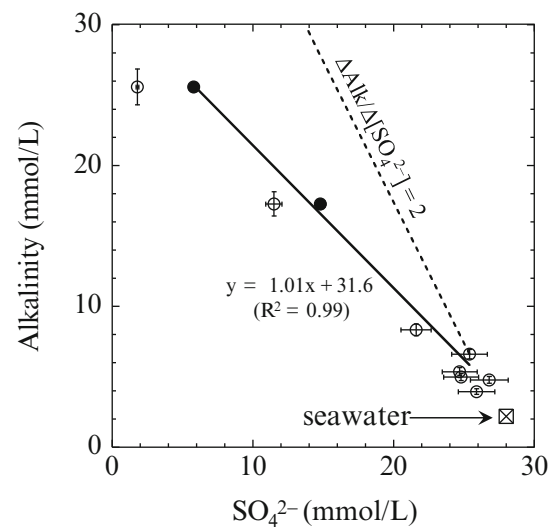

Fig. 31.8 (a) Magnesium versus chloride concentrations and (b) magnesium versus sulfate concentrations in the pore water of Core $1188 \mathrm{MB}$. The dotted line extending from the seawater value represents the mixing line between seawater and the Biwako hydrothermal fluid. Solid lines are the linear regression lines for three datasets (8-23 cmbsf) showing the input of the Biwako fluid into the pore water. (c) Relationship between sulfate concentration and alkalinity in the pore water of Core $1188 \mathrm{MB}$. The dotted line (extending from the data of 6-8 cmbsf) represents the increase in alkalinity with decreasing sulfate in $\Delta \mathrm{Alk} / \Delta\left[\mathrm{SO}_{4}{ }^{2-}\right]=2$, which is based on ideal $\mathrm{SR}$ and AOM processes. The filled circles in (b) and (c) are the estimated values for sulfate concentration in pore water below 10 cmbsf excluding the contribution of the Biwako fluid. The solid line in (c) represents the linear regression line for the two measured data (6-10 cmbsf) and the two predicted data without the contribution of the Biwako fluid (10-23 cmbsf) is somewhat larger but of the same order as the $\mathrm{NH}_{4}{ }^{+}$ concentration observed at 10-17 cmbsf (0.43 mmol/L), suggesting that the increase in $\mathrm{NH}_{4}{ }^{+}$concentration in the deeper layer is attributed to the input of Biwako fluid into the pore water. The input of Biwako fluid can cause a decrease in the sulfate concentration in the pore water because of the absence of sulfate in the Biwako fluid. However, three pore water samples within the deeper layer (8-23 cmbsf) significantly deviate from the mixing line between the seawater and the Biwako hydrothermal fluid endmembers (Fig. 31.8b). This suggests that another sulfate removal process occurs below $8 \mathrm{cmbsf}$ in Core $1188 \mathrm{MB}$.

Since alkalinity in the Biwako hydrothermal fluid has not been reported previously, it is difficult to estimate the effect of the input of the Biwako fluid on the alkalinity of the pore water. As mentioned before, however, the alkalinity in the pore water of Core $1188 \mathrm{MB}$ (up to $25.6 \mathrm{mmol} / \mathrm{L}$ ) far exceeds the alkalinity in the surrounding hydrothermal fluid (e.g., $1.5 \mathrm{mmol} / \mathrm{L}$ in the Jade fluid (Sakai et al. 1990b)). The significant increase in alkalinity with increasing depth may be related to another sulfate removal process described above. Along with the depth, the alkalinity profile is inversely correlated with the sulfate concentration profile (Fig. 31.8c). Note that the apparent decrease in sulfate concentration is partially caused by the mixing with Biwako fluid below $10 \mathrm{cmbsf}$. This mixing effect could be estimated based on the decreasing rate of magnesium concentration within 8-23 cmbsf, and is excluded from the data to discuss another sulfate removal process (plotted as filled circles in Fig. $31.8 b, c)$. After this elimination of the mixing 
component, the ratio of increased alkalinity (Alk) and decreased sulfate concentrations $\left(=\Delta \mathrm{Alk} / \Delta\left[\mathrm{SO}_{4}{ }^{2-}\right]\right)$ is estimated as 1.01 in atomic ratio (Fig. $31.8 \mathrm{c}$ ).

The simultaneous decrease of sulfate concentration and increase of alkalinity toward the deeper parts at the sedimentary seafloor have often been interpreted as the effect of sulfate reduction (SR) and anaerobic oxidation of methane (AOM) (e.g., Gamo et al. 1991; Chatterjee et al. 2011). The Biwako fluid is characterized by high contents of volatile species originating from the Jade fluid. Since the Jade fluid is enriched in methane $(7.6 \mathrm{mmol} / \mathrm{L}$ ) (Ishibashi et al. 1995), the methane is expected to be supplied along with the Biwako fluid to Core 1188MB. Stoichiometry of SR for sedimentary organic matter is frequently described as follows, using the Redfield ratio $(\mathrm{C}: \mathrm{N}: \mathrm{P}=106: 16: 1$ by atoms), which represents the ideal composition of phytoplankton (Redfield 1958):

$$
\begin{aligned}
& \left(\mathrm{CH}_{2} \mathrm{O}\right)_{106}\left(\mathrm{NH}_{3}\right)_{16}\left(\mathrm{H}_{3} \mathrm{PO}_{4}\right)+53 \mathrm{SO}_{4}^{2-} \\
& \rightarrow 106 \mathrm{HCO}_{3}^{-}+16 \mathrm{NH}_{4}^{+}+53 \mathrm{HS}^{-} \\
& +\mathrm{H}_{3} \mathrm{PO}_{4}+37 \mathrm{H}^{+}
\end{aligned}
$$

The ratio of the produced alkalinity and consumed sulfate concentrations $\left(=\Delta \mathrm{Alk} / \Delta\left[\mathrm{SO}_{4}{ }^{2-}\right]\right)$ during $\mathrm{SR}$ is estimated as $2(=(106+53-16-37) / 53)$. However, the increased $\mathrm{NH}_{4}{ }^{+}$ concentration at $10-17 \mathrm{cmbsf}$ could be explained only by the input of the Biwako fluid into the pore water as described above. Therefore, SR is not considered to be associated with another sulfate removal process observed below $8 \mathrm{cmbsf}$ in Core $1188 \mathrm{MB}$. The other sulfate-consuming reaction, AOM, can be expressed as

$$
\mathrm{CH}_{4}+\mathrm{SO}_{4}^{2-} \rightarrow \mathrm{HCO}_{3}^{-}+\mathrm{HS}^{-}+\mathrm{H}_{2} \mathrm{O}
$$

which can increase the alkalinity without changing the $\mathrm{NH}_{4}{ }^{+}$ concentration in the pore water. The increase in alkalinity corresponds to releases of bicarbonate and hydrogen sulfide $\left(\mathrm{HS}^{-}\right)$, resulting in a $\Delta \mathrm{Alk} / \Delta\left[\mathrm{SO}_{4}{ }^{2-}\right]$ ratio of 2 in the AOM. Assuming that AOM occurs, the increase in alkalinity below $8 \mathrm{cmbsf}$ in Core $1188 \mathrm{MB}\left(\Delta \mathrm{Alk} / \Delta\left[\mathrm{SO}_{4}{ }^{2-}\right]=1.01\right)$ is stoichiometrically insufficient (Fig. 31.8c). This inconsistency of the $\Delta \mathrm{Alk} / \Delta\left[\mathrm{SO}_{4}{ }^{2-}\right]$ ratio can be explained by considering the presence of native sulfur in Core $1188 \mathrm{MB}$, as described below.

The sulfate consumption by AOM releases dissolved hydrogen sulfide to the pore water in Core 1188MB. Simultaneously, the input of the Biwako fluid raises the concentration of hydrogen sulfide in the pore water because of its high concentration in the Biwako fluid $(23 \mathrm{mmol} / \mathrm{L})$. Under the $\mathrm{pH}$ condition in Core $1188 \mathrm{MB}(\mathrm{pH}>7.4)$, hydrogen sulfide could be dissolved as $\mathrm{HS}^{-}$(Fig. 31.7). The concentration of $\mathrm{HS}^{-}$, however, was considerably low throughout Core $1188 \mathrm{MB}$. Furthermore, the $\mathrm{pH}$ of the pore water remains at seawater-level $\mathrm{pH}$ value over the whole sediment core despite the mixing with the acidic Biwako fluid (pH 4.8). These apparent inconsistencies in terms of $\mathrm{HS}^{-}$ and $\mathrm{pH}$ in the pore water can be explained by the precipitation of native sulfur, which was found throughout Core 1188MB. When the acidic and anoxic Biwako fluid encounters the relatively oxic sediment pore water, the $\mathrm{HS}^{-}$in the Biwako fluid and sulfate in the pore water are converted into intermediate valence sulfur, i.e., native sulfur, as follow:

$$
3 \mathrm{HS}^{-}+\mathrm{SO}_{4}^{2-}+5 \mathrm{H}^{+} \rightarrow 4 \mathrm{~S}_{(\mathrm{s})}+4 \mathrm{H}_{2} \mathrm{O}
$$

The reaction in Eq. (31.15) could inhibit the acidification of the pore water by the consumption of protons supplied from the acidic Biwako fluid. In addition, $\mathrm{HS}^{-}$originating from the Biwako fluid and AOM can be consumed by reaction in Eq. (31.15), resulting in depletion of $\mathrm{HS}^{-}$in the pore water.

A previous sulfur isotope study has suggested that the sulfur crust near the Biwako vent was formed by disequilibrium precipitation of native sulfur during exhalation of hydrothermal fluid into cold seawater on the seafloor (Marumo and Hattori 1999). In the case of Core 1188MB, this encounter of hydrothermal fluid and seawater occurs within the subsurface sediment deeper than $10 \mathrm{cmbsf}$ at present, and the resulting native sulfur formation could occur extensively below Core 1188MB. However, native sulfur was found immediately below the seafloor in Core $1188 \mathrm{MB}$. This wide distribution of native sulfur, as well as the commonly-found hydrothermal clay minerals (illite, smectite, and chlorite), may reflect the past fluid input into the sediment. The presence of iron oxyhydroxide (ferrihydrite) and sulfate (barite), which were identified by XAFS analysis for Core $1188 \mathrm{MB}$, indicate that the oxic condition is maintained only in the shallowest sediment near the seafloor.

When the $\mathrm{HS}^{-}$is removed from the pore water by the precipitation of native sulfur, only the release of bicarbonate during reaction in Eq. (31.14) contributes to the increase in alkalinity in AOM. The net $\Delta \mathrm{Alk} / \Delta\left[\mathrm{SO}_{4}{ }^{2-}\right]$ ratio is expected to be 1 (Eq. 31.14), which agrees with the $\Delta \mathrm{Alk} / \Delta\left[\mathrm{SO}_{4}{ }^{2-}\right]$ ratio below $8 \mathrm{cmbsf}$ in Core $1188 \mathrm{MB}(=1.01)$. Hence, the formation of native sulfur in Core $1188 \mathrm{MB}$ can be associated with AOM below $8 \mathrm{cmbsf}$ and the input of the Biwako fluid into the sediment below $10 \mathrm{cmbsf}$.

\subsection{Summary}

The sediment samples collected by coring from two active hydrothermal vents are characterized by the common occurrence of native sulfur; however, the two sediments show 
Fig. 31.9 Schematic models of subsurface sediment-pore water system involving native sulfur formation in the Jade hydrothermal field. (a) The seawater recharge system observed in Core 1186MBL. (b) The hydrothermal fluid-seawater mixing system observed in Core $1188 \mathrm{MB} . S W L$ sea water level

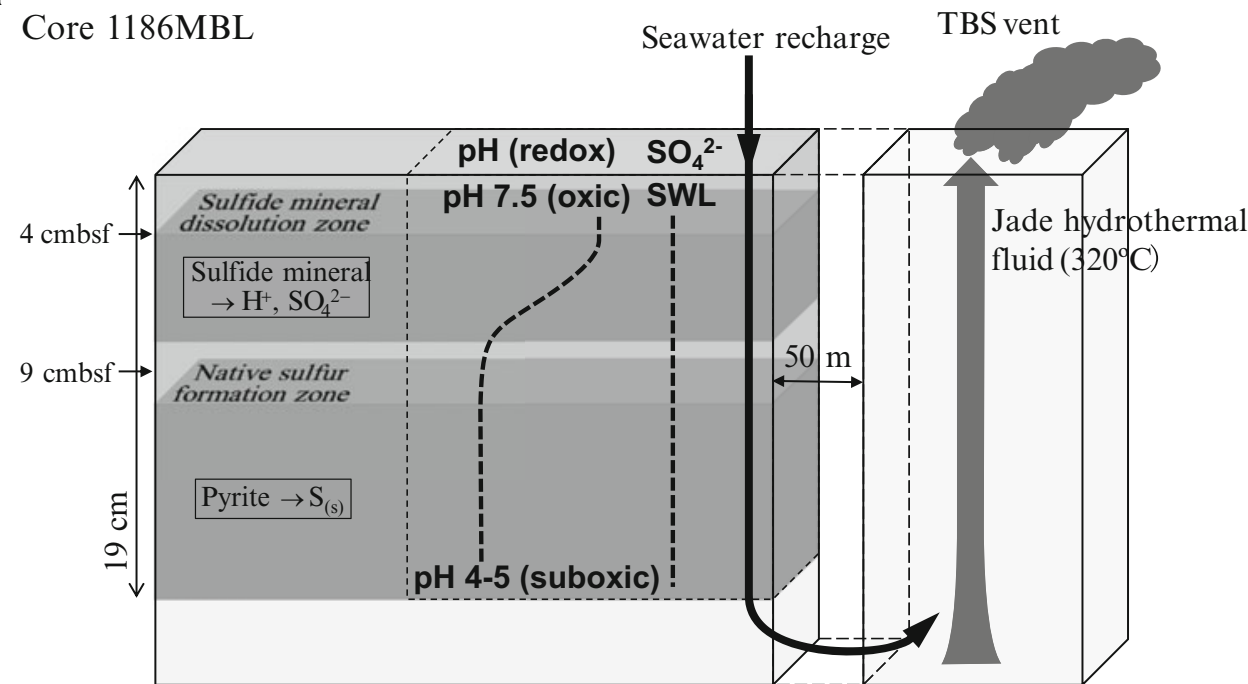

b

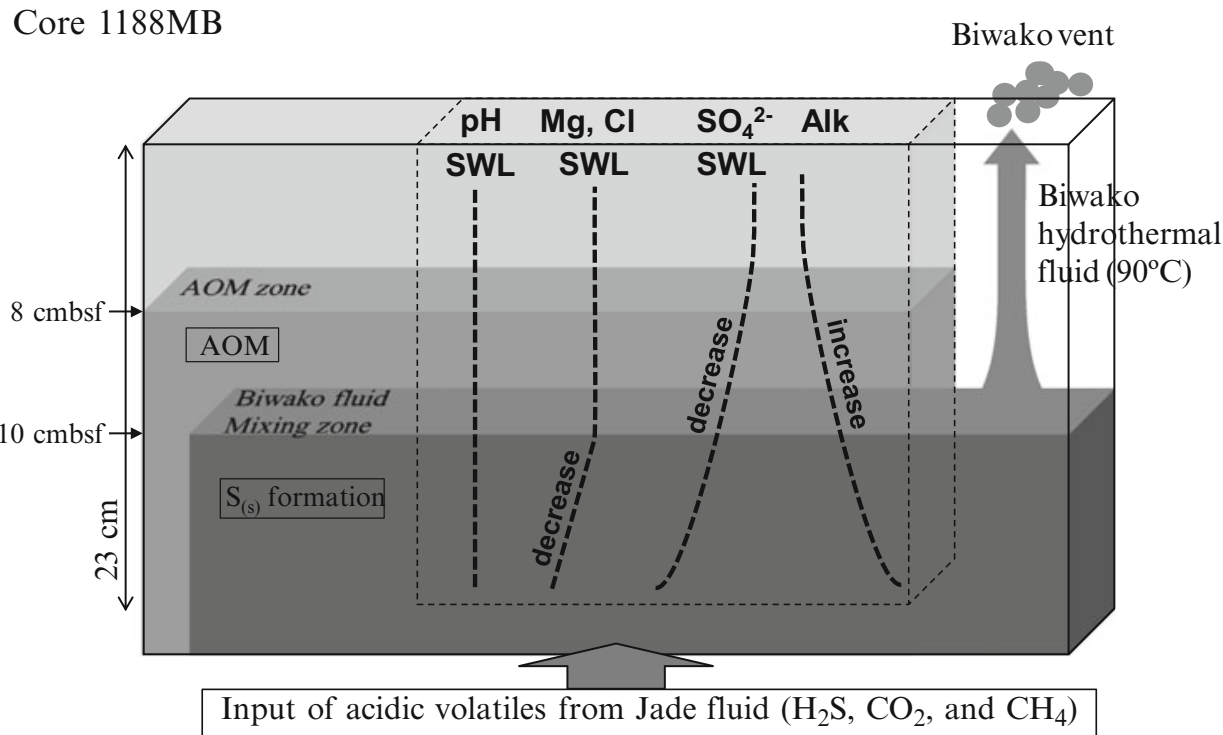

quite different pore water chemistry (Fig. 31.9). The sediment collected near the TBS vent (Core 1186MBL) is characterized by chimney fragments in the shallower part (2-9 cmbsf) and native sulfur in the deeper part (6-19 cmbsf). The chemical composition of the pore water implies that seawater penetrates into the sediment downward to form secondary fluid circulation cell. This seawater could oxidize and dissolve sulfide minerals in the chimney fragments at the shallower part, resulting in the transport of acidic and suboxic pore water toward the deeper part. The precipitation of native sulfur in the deeper part is considered to be derived from the acidic and suboxic pore water. The other sediment collected near the Biwako vent (Core 1188MB) shows the involvement of the Biwako fluid in the pore water below 10 cmbsf, and the AOM below 8 cmbsf. The active AOM could be explained by the input of the volatile-rich vapor phase produced by subcritical phase separation, which raises pore water alkalinity significantly with increasing depth. The uniform $\mathrm{pH}$ condition and depletion of hydrogen sulfide in the pore water throughout Core $1188 \mathrm{MB}$ despite the input of hydrothermal fluid and AOM may be attributed to the precipitation of native sulfur. The wide distribution of native sulfur throughout the sediment core may reflect past fluid input into the sediment. The roles of native sulfur formation in the sediment-pore water systems are obviously different between the two sediment cores. The native sulfur formation in Core $1186 \mathrm{MBL}$ is the result of the acidic condition created by the sulfide dissolution, while the precipitation of the native sulfur maintains the circumneutral $\mathrm{pH}$ condition in Core $1188 \mathrm{MB}$. The occurrence of native sulfur also implies 
the seawater recharge in Core $1186 \mathrm{MBL}$, and the input of hydrothermal fluid to the sediment and AOM in Core $1188 \mathrm{MB}$. These are common events in sub-seafloor hydrothermal systems, and native sulfur might be an indicator of these important geochemical events in the sediment-pore water system of arc-back-arc hydrothermal fields.

Acknowledgments This study was supported by a Grant-in-Aid for Scientific Research on Innovative Areas from the Ministry of Education, Culture, Sports, Science and Technology (MEXT) of Japan including the "TAIGA" project accepted as a Scientific Research on Innovative Areas (Grant Number: 20109004), and by the JSPS Research Fellowships for Young Scientists. This work has been performed with the approval of KEK (Proposal No. 2012G111 and 2013G052) and SPring-8/JASRI (2011B1673, 2012B1564, and 2013B1116).

Open Access This chapter is distributed under the terms of the Creative Commons Attribution Noncommercial License, which permits any noncommercial use, distribution, and reproduction in any medium, provided the original author(s) and source are credited.

\section{References}

Baumgartner R, Fontboté L, Vennemann T (2008) Mineral zoning and geochemistry of epithermal polymetallic $\mathrm{Zn}-\mathrm{Pb}-\mathrm{Ag}-\mathrm{Cu}-\mathrm{Bi}$ mineralization at Cerro de Pasco, Peru. Econ Geol 103:493-537. doi:10. 2113/gsecongeo.103.3.493

Bethke C (2011) The Geochemist's workbench software package (version 9.0). University of Illinois, Urbana-Champaign

Brookins DG (1987) Eh-pH diagrams for geochemistry. Springer, Berlin

Butterfield DA, Seyfried WE, Lilley MD (2003) Composition and evolution of hydrothermal fluids. In: Halbach PE et al (eds) Energy and mass transfer in marine hydrothermal systems. Dahlem University Press, Germany, pp 124-161

Chatterjee S, Dickens GR, Bhatnagar G, Chapman WG, Dugan B, Snyder GT, Hirasaki GJ (2011) Pore water sulfate, alkalinity, and carbon isotope profiles in shallow sediment above marine gas hydrate systems: a numerical modeling perspective. J Geophys Res 116, B09103. doi:10.1029/2011JB008290

Cline JD (1969) Spectrophotometric determination of hydrogen sulfide in natural waters. Limnol Oceanogr 14:454-458

de Ronde CEJ, Massoth GJ, Butterfield DA, Christenson BW, Ishibashi J, Ditchburn RG, Hannington MD, Brathwaite RL, Lupton JE, Kamenetsky VS, Graham IJ, Zellmer GF, Dziak RP, Embley RW, Dekov VM, Munnik F, Lahr J, Evans LJ, Takai K (2011) Submarine hydrothermal activity and gold-rich mineralization at Brothers Volcano, Kermadec Arc, New Zealand. Miner Deposita 46:541-584. doi:10.1007/s00126-011-0345-8

Embley RW, Baker ET, Butterfield DA, Chadwick WW Jr, Lupton JE, Resing JA, de Ronde CEJ, Nakamura K, Tunnicliffe V, Dower JF, Merle SG (2007) Exploring the submarine ring of fire: Mariana Arc - Western Pacific. Oceanography 20(4):68-79. doi:10.5670/ oceanog.2007.07

Gamo T, Sakai H, Kim ES, Shitashima K, Ishibashi J (1991) High alkalinity due to sulfate reduction in the CLAM hydrothermal field, Okinawa Trough. Earth Planet Sci Lett 107(2):328-338. doi:10. 1016/0012-821X(91)90080-2

Gamo T, Ishibashi J, Tsunogai U, Okamura K, Chiba H (2006) Unique geochemistry of submarine hydrothermal fluids from arc-back-arc settings of the western Pacific. In: Christie DM et al (eds) Back-arc spreading systems: geological, biological, chemical and physical interactions, vol 166, Geophysical monograph. AGU, Washington, DC, pp 147-161. doi:10.1029/166GM08

Halbach P, Nakamura K-I, Wahsner M, Lange J, Sakai H, Käselitz L, Hansen R-D, Yamano M, Post J, Prause B, Seifert R, Michaelis W, Teichmann F, Kinoshita M, Märten A, Ishibashi J, Czerwinski S, Blum N (1989) Probable modern analogue of Kuroko-type massive sulphide deposits in the Okinawa Trough back-arc basin. Nature 338(6215):496-499. doi:10.1038/338496a0

Ishibashi J, Sano Y, Wakita H, Gamo T, Tsutsumi M, Sakai H (1995) Helium and carbon geochemistry of hydrothermal fluids from the mid-Okinawa Trough back-arc basin, Southwest of Japan. Chem Geol 123(1-4):1-15. doi:10.1016/0009-2541(95)00051-M

Ishibashi J, Noguchi T, Toki T, Miyabe S, Yamagami S, Onishi Y, Yamanaka T, Yokoyama Y, Omori E, Takahashi Y, Hatada K, Nakaguchi Y, Yoshizaki M, Konno U, Shibuya T, Takai K, Inagaki F, Kawagucci S (2014) Diversity of fluid geochemistry affected by processes during fluid upwelling in active hydrothermal fields in the Izena Hole, the middle Okinawa Trough back-arc basin. Geochem J 48(3):357-369. doi:10.2343/geochemj.2.0311

Kawagucci S, Chiba H, Shibash J, Yamanaka T, Toki T, Muramatsu Y, Ueno Y, Makabe A, Inoue K, Yoshida N, Nakagawa S, Nunoura T, Takai K, Takahata N, Sano Y, Narita T, Teranishi G, Obata H, Gamo T (2011) Hydrothermal fluid geochemistry at the Iheya North field in the mid-Okinawa Trough: implication for origin of methane in subseafloor fluid circulation systems. Geochem J 45(2):109-124

Kinoshita M, Yamano M (1997) Hydrothermal regime and constraints on reservoir depth of the Jade site in the Mid-Okinawa Trough inferred from heat flow measurements. J Geophys Res 102 (B2):3183-3194. doi:10.1029/96JB03556

Manceau A, Marcus MA, Tamura N (2002) Quantitative speciation of heavy metals in soils and sediments by synchrotron X-ray techniques. In: Fenter PA, Rivers ML, Sturchio NC, Sutton SR (eds) Applications of synchrotron radiation in low-temperature geochemistry and environmental science, vol 49. Reviews in Mineralogy and Geochemistry, Mineralogical Society of America. pp 341-428, doi:10.2138/gsrmg.49.1.341

Marumo K, Hattori KH (1999) Seafloor hydrothermal clay alteration at JADE in the back-arc Okinawa Trough: mineralogy, geochemistry and isotope characteristics. Geochim Cosmochim Acta 63 (18):2785-2804. doi:10.1016/S0016-7037(99)00158-1

Moses CO, Nordstrom DK, Herman JS, Mills AL (1987) Aqueous pyrite oxidation by dissolved oxygen and by ferric iron. Geochim Cosmochim Acta 51(6):1561-1571. doi:10.1016/0016-7037(87) 90337-1

Nakagawa T, Takai K, Suzuki Y, Hirayama H, Konno U, Tsunogai U, Horikoshi K (2006) Geomicrobiological exploration and characterization of a novel deep-sea hydrothermal system at the TOTO caldera in the Mariana Volcanic Arc. Environ Microbiol 8 (1):37-49. doi:10.1111/j.1462-2920.2005.00884.x

Nordstrom DK (1982) Aqueous pyrite oxidation and the consequent formation of secondary iron minerals. In: Kittrick JA, Fanning DS, Hossner LR (eds) Acid sulfate weathering. Soil Science Society of America Special Publication 10, Madison, pp 37-46

O'Day PA, Rivera N, Root R, Carroll SA (2004) X-ray absorption spectroscopic study of $\mathrm{Fe}$ reference compounds for the analysis of natural sediments. Am Mineral 89(4):572-585

Pickering IJ, Brown GE, Tokunaga TK (1995) Quantitative speciation of selenium in soils using X-ray absorption spectroscopy. Environ Sci Technol 29(9):2456-2459. doi:10.1021/es00009a043

Pingitore NE, Meitzner G, Love KM (1995) Identification of sulfate in natural carbonates by X-ray absorption spectroscopy. Geochim Cosmochim Acta 59(12):2477-2483. doi:10.1016/0016-7037(95) 00142-5 
Ravel B, Newville M (2005) ATHENA, ARTEMIS, HEPHAESTUS: data analysis for X-ray absorption spectroscopy using IFEFFIT. J Synchrotoron Rad 12(4):537-541. doi:10.1107/ s0909049505012719

Redfield AC (1958) The biological control of chemical factors in the environment. Am Sci 46(3):205-221

Sakai H, Gamo T, Ishibashi J, Shitashima K, Kim E-S, Yanagisawa F, Tsutsumi M, Sano Y, Wakita H, Tanaka T, Matsumoto T, Naganuma T, Mitsuzawa K (1990a) Unique chemistry of the hydrothermal solution in the mid-Okinawa Trough Backarc Basin. Geophys Res Lett 17(12):2133-2136. doi:10.1029/ GL017i012p02133

Sakai H, Gamo T, Kim E-S, Tsutsumi M, Tanaka T, Ishibashi J, Wakita H, Yamano M, Oomori T (1990b) Venting of carbon dioxide-rich fluid and hydrate formation in mid-Okinawa Trough Backarc Basin. Science 248(4959):1093-1096. doi:10.1126/sci ence.248.4959.1093

Scheinost AC, Charlet L (2008) Selenite reduction by mackinawite, magnetite and siderite: XAS characterization of nanosized redox products. Environ Sci Technol 42(6):1984-1989. doi:10.1021/ es071573f

Schroeder SLM (1996) Towards a 'universal curve' for total electronyield XAS. Solid State Commun 98(5):405-409. doi:10.1016/00381098(96)00035-X

Solorzano L (1969) Determination of ammonia in natural waters by the phenol hypochlorite method. Limnol Oceanogr 14(5): 799-801

Stein JS, Fisher AT (2001) Multiple scales of hydrothermal circulation in Muddle Valley, northern Juan de Fuca Ridge: physical constraints and geologic models. J Geophys Res 106:8563-8580. doi:10.1029/2000JB900395

Tsuji K, Nakano K, Takahashi Y, Hayashi K, Ro C-U (2012) X-ray spectrometry. Anal Chem 84(2):636-668. doi:10.1021/ac202871b

van Hullenbusch E, Farges F, Lenz M, Lens P, Brown GE (2007) Selenium speciation in biofilms from granular sludge bed reactors used for wastewater treatment. AIP Conf Proc 882(1):229-231. doi: $10.1063 / 1.2644483$ 